
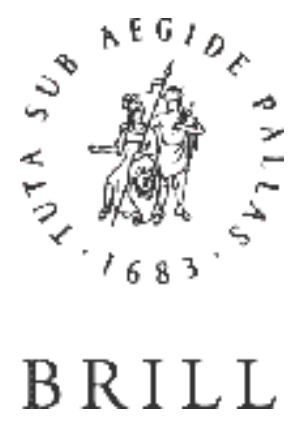

\title{
Review: Global History of Science Comes of Age
}

Reviewed Work(s): Science and Technology in World History. An Introduction by James E. McClellan and Harold Dorn

Review by: H. Floris Cohen

Source: Early Science and Medicine, Vol. 6, No. 4, Science and Universities of Early Modern Europe: Teaching, Specialization, Professionalization (2001), pp. 362-368

Published by: Brill

Stable URL: https://www.jstor.org/stable/4130322

Accessed: 01-12-2021 07:18 UTC

JSTOR is a not-for-profit service that helps scholars, researchers, and students discover, use, and build upon a wide range of content in a trusted digital archive. We use information technology and tools to increase productivity and facilitate new forms of scholarship. For more information about JSTOR, please contact support@jstor.org.

Your use of the JSTOR archive indicates your acceptance of the Terms \& Conditions of Use, available at https://about.jstor.org/terms 


\title{
REVIEW ESSAY
}

\section{GLOBAL HISTORY OF SCIENCE COMES OF AGE}

\author{
H. FLORIS COHEN
}

James E. McClellan III \& Harold Dorn, Science and Technology in World History. An Introduction (Baltimore and London: Johns Hopkins University Press, 1999), pp. viii. + 404 Ǔ 57.00 ISBN 0801858682 (bound); Ŭ 19.95 ISBN 0801858690 (paperback).

The preface all too modestly presents this book as just an introductory text for undergraduates and educated laypersons. While assiduously concerned to digest and use up-to-date scholarly interpretations, the authors lay no claim to independent scholarly merits. But since in my opinion the book (in addition to providing an apparently well-tested and most commendable classroom text) does possess considerable such merits, but also displays several features that rather needlessly detract from them, I shall here present and review the book in both capacities.

In a lemma recently written for an encyclopedia and directed at 'general' historians, I noted that "there is no overview of the whole of Western science that meets present-day standards. Existing efforts, while courageous, have tended to turn into either popular heroics or factual chronicles or somewhat spotty selections from the point onward where the Scientific Revolution is left behind ... It is striking how rarely efforts have been made to integrate the history of science into history at large, just as it is striking how rarely 'general' historians have contributed insights of their own to an understanding of the past of science, whether by itself or in its social and its cultural contexts. A big gap has been yawning here ... For despite the remoteness, to the 'general' historian, of the object of prime concern to the historian of science, science has become a constituent of our culture that 'general' historians may ignore only at considerable intellectual costs."

\footnotetext{
${ }^{1}$ H. Floris Cohen, 'Science, History of,' in D.R. Woolf (ed.), A Global Encyclopaedia of Historical Writing, 2 vols. (New York, 1998), 2: 816-819. 
It is indeed a pleasure for me to be able to preface the present review with the bald statement that this complaint of mine, published one year before McClellan \& Dorn's book came out, has already lost its point.

More than that, really, as the authors have gone way beyond treating the entire history of all of Western science, in that their story has been made to include science in all of the non-Western traditions we know of as well as the world history of technology. Moving from Stonehenge to superstrings in just 373 pages (with wide margins for captions to the numerous illustrations, leaving an average of c. 400 words per page), the authors manage to be neither popularly heroic, nor just chronicle-factual, nor (generally speaking) spotty. How, one wonders, have they done it?

Two story lines, in particular, lend the account needed coherence without (as a rule) unduly squeezing the material handled by them into preset patterns.

Their first story line derives from Dorn's The Geography of Science of 1991. The leading thesis of that boldly challenging book hinges on a distinction between two modes of science, one fully dependent on, and institutionally integrated in, centralized state bureaucracies and hence directed toward rather narrowly utilitarian purposes; the other largely autonomous, curiosity-directed, unconnected to any state or state-like structure, cultivated by (in a social sense) freely floating individuals. The former type is characteristic of civilizations dependent for their coming-into-being and for their ongoing survival on techniques of water management and on the organized mass labor force needed to keep it going. The latter is found in those rare civilizations which, set in temperate climates with regular, moderate rainfall, where sufficient water evenly spreads without causing severe problems of draining, lack the basic incentive for the creation of the power monopoly of a central state. Prior to modern times, the former mode of science has been the rule-so Dorn here once again argues, thus setting Greece and (later, also decreasingly so) Western Europe as the sole cases of the latter type against Egypt, Mesopotamia, China, Islam civilization, India, the empire of the Khmer, and a range of preColumbian civilizations in Middle-, South-, and North-America. Regardless of how analytically fertile for the history of science one may find this basic and, by itself, well-established distinction between hydraulic and non-hydraulic civilizations, in the present 
book it surely works well to attain two important aims. Dorn's thesis connects the history of science with politics and warfare, with agrarian and urban economics, with ecological concerns and related demographic issues, with matters of social stratification, in short, with by and large the entire panel of history, in a much more natural manner than those desperate 'and now for the political etc. background' sections with which, e.g., J.D. Bernal or Bertrand Russell once sought to turn what was really history of ideas into something more than that. The same aim of connecting science to society is also being fulfilled here in a generally more satisfactory way than in much that nowadays passes for social history of science but is too rarely about other social relations than those between scientists themselves. Further, Dorn's thesis pulls together what, without it, might easily have slipped into a range of just-so stories about the science and technology of China and all those other civilizations with more or less flourishing but always noteworthy scientific traditions of which nonetheless (fully twothirds of a century after Joseph Needham got started) a wholesale neglect by historians of science has remained the general rule.

These are considerable merits indeed. Virtually all preceding efforts at drawing a somewhat similarly big picture have either dispensed with a guiding thread, thus producing profoundly boring and unconnected sequences of discoveries and inventions, or have taken as their guiding theme the remorseless triumph of the alleged scientific method, thus turning their accounts into an almost equally boring listing of the successive 'roots' of the seemingly pre-ordained successes of our own time. Free of the resulting positivist distorsions and also blessed with an enviable didactic ability to explain difficult historical-scientific issues in a clear-cut, well-informed, non-trivial manner, and to leave out many details so as to gain space for the unhurried treatment of the truly significant, the present book would easily be the best text available even if its authors had limited themselves to the Western tradition. But they have rightly observed that once present-day science ceases to be seen as the ultimate end and direct goal of everything that preceded it, then all scientific traditions the world has known are entitled to treatment in their own right. As noted, Dorn's hydraulic thesis serves to bind these successive treatments together.

The other story line is that of the perennial separation between science and technology up to the nineteenth century. This, too, is, 
in principle, a wholesome reversal of almost all preceding big-picture accounts, with their tacitly adopted tendency to project the post-Industrial-Revolution intertwinement of technology and science back upon earlier periods. Up to the nineteenth century, technology is handled in the present book in close historical connection, not with science but with water works in the first place and with all that served to make life in pre-modern civilizations feasible and (if one were lucky) amenable, like crop cultivation, cooking, housing, warfare (its techniques get much well-deserved attention, in particular Western Europe's 'Military Revolution' of the fifteenth/sixteenth centuries) or transportation. Time and again the authors point out that, although craftsmen out to make these things possible can be seen by us to employ certain underlying scientific principles, their inventions were due to experiencetested, ingenious manipulations, and subsequent traditional handling to accumulated experience laid down orally in rules of thumb, hardly ever to the conscious application of known scientific principles. To the small extent that there was a connection, so the authors maintain, it worked the other way round, with the craftsman on occasion setting puzzles for the scholar (e.g., how to account for the operation of telescopes).

It is of course well possible to overstate these two leading theses. One of the charming features of this book is that evidence flying in the face of the authors' occasional overstatement is as a rule presented by themselves. For example, in their effort to deny any direct connection between the Scientific and the Industrial Revolutions they go out of their way to portray Thomas Newcomen as just an ingenious craftsman. In so doing they of course mention (albeit in passing) his handling of atmospheric pressure, but forget entirely what they have related only a few chapters before (albeit indeed with insufficient emphasis) about the seventeenth century's scientific discovery that the atmosphere exerts pressure in the first place. ${ }^{2}$ They similarly manage to overlook such genuinely scientific insights as went into the fundamental accomplishments of, e.g., James Watt (who obtained several such insights himself) or John Harrison (who picked them up indirectly). In

${ }^{2}$ I have taken up this question at length in my Dutch article 'Het ontstaan van onze moderne wereld: wat natuurwetenschap en techniek ermee van doen hadden' ['The rise of our modern world: What science and technology had to do with it'), Theoretische Geschiedenis 25 (1998), 322-349. 
short, what they miss in their persistent effort to downplay any realization, prior to nineteenth-century Britain, of the Baconian promise is an awareness that throughout the eighteenth century, on the Continent and more successfully in Britain, ways and means were being explored to bridge an ever more clearly noticed and increasingly well understood disparity between science and technology, which led to the emergence of such superior craftsmen of an unprecedented, learned type, represented precisely by men such as Newcomen, Watt, or Harrison.

Overstatement also marks Dorn's hydraulic thesis. The most glaring exaggeration in my opinion concerns China. Directly after arguing that China fully conformed to the hydraulic pattern of bureaucracy-serving, use-oriented science, the authors go on to outline China's definitely non-utilitarian, natural-philosophical framework of 'organic materialism' (in Needham's phrase). Thus they obscure beyond rescue what seems to me to constitute a basic fact of the pre-modern world: that there were many civilizations which displayed flourishing elements of science (most often astronomical and calendrical), but only two civilizations which in addition developed fairly detailed, 'naturalist' conceptions of their own about how the world at large is constituted. In other words, not Greece is the big exception, but Greece and China constitute together the big exceptions, which cuts right through Dorn's primary distinction between hydraulic and non-hydraulic societies. Also, once one begins to reflect in a comparative sense on how similar Islamic civilization and Renaissance (not medieval) Europe were in their handling of the Greek legacy until the latter took an epochal turn without counterpart in the former, the significance for science of the surely huge political/societal differences between these two civilizations begins to dwindle. However, Dorn \& McClellan have chosen not to take a comparative approach to their world history, which some readers will find a pity, but others will applaud.

One other remarkable feature of this book is the authors' careful avoidance of the kind of information explosion one so often finds in surveys once they move beyond Sir Isaac. This temporal threshold is taken in the present book on p. 273, with just 100 more to follow. Those 100 pages, called upon to cover the eighteenth, nineteenth, and twentieth centuries, are given order and coherence in part by means of the thesis (already mentioned) of 
'science finally meeting technology', but also by a judicious application of Thomas Kuhn's celebrated distinction between the classical-mathematical and the Baconian sciences and the onset of their integration by the turn of the nineteenth century. Chapters on the Darwinian Revolution, on the spread of industrialization, on relativist and quantum physics and what these entail for our picture and handling of the world, and a particularly thoughtful chapter on 'applied science and technology today' round off the book in a manner that enables the reader to go on feeling in control of the really plentiful information amassed here.

It is of course humanly impossible to make a two-author book of this scope grow out of more than bits and pieces of original research. In facing such a self-set task the best one can do is pick the best literature on each topic, focus on its main points, render them with fair even-handedness within the framework of one's own theses, where at all applicable, and stay critical throughout. With the exception of the final clause, this is indeed by and large how our authors have proceeded; their book may well be described as the sensibly toned, generally undogmatic, generally enlightening stringing together of pieces of frequently well-chosen literature on an enormous variety of topics taken up one after another in functionally comprehensible order. But they have not been critical enough-in several respects their reliance on what they found in the literature has gone too far. Numerous statements on interpretive points of some significance are not just disputable but downright wrong (like the unambiguous attribution to Chinese clocks of a mechanical escapement, or the idea that Aristotelianism became the dominant natural philosophy right from the start rather than in Western Islam for the first time). Sometimes they sum up a piece of literature in their customary, fair and balanced manner, without apparently realizing that its conclusions, which are left standing, contradict their own stated views (e.g., in the cases of Needham or Shapin \& Schaffer). Also, despite their generally judicious distinction between the essential or the telling kept in and the accidental left out, one misses some protagonists who really should not have been omitted, like Helmholtz (just absent) or Leonardo (mentioned in passing and only as a painter). Further, since the authors never append any caveat to their frequent invocation of numbers (populations, crop yields, etc.), the innocent reader will have no idea of the large amount of salt with which one 
must consume the great majority of numerical data concerning the periods preceding the age of statistics. With regard to just plain facts, a book like this is always hard to judge by a single reviewer. In one's own domain of expertise, one encounters one's fair share of at least dubious assertions. But how to pass judgment on the tenability of what is being said concerning those far more numerous domains of which one is ignorant? One hopes that this book gets reviews from many quarters, and that the authors will address the collected points of criticism in a second edition I heartily desire for this book which, whatever its merits and defects in terms of all pertinent specialisms, seems to me well placed to grab and stir our students and educated laypersons alike, and no less wellplaced to inform ourselves, professional historians of science, about many things we really should know about but generally do not. 